\title{
Estimation of Oleoresin yield from Copaifera spp. in primary forest in meridional Amazon
}

\section{Estimación de rendimiento de aceite de Copaifera spp. en bosque primario en la Amazonia meridional}

\author{
José Guilherme Roquette ${ }^{1 *}$, Ronaldo Drescher ${ }^{2}$, Gilvano Ebling Brondani ${ }^{3}$, Edila Cristina Souza2 \\ Rubens Marques Rondon-Neto ${ }^{4}$, Alexandre Ebert ${ }^{5}$, and Leandro Ribeiro Teixeira ${ }^{6}$
}

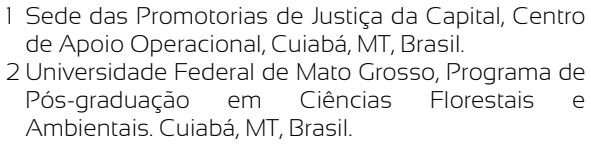

\author{
3 Universidade Federal de Lavras, Departamento de \\ Ciências Florestais, Lavras, MG, Brasil. \\ 4 Universidade Estadual de Mato Grosso \\ Departamento de Engenharia Florestal, Alta Floresta, \\ MT, Brasil
}

\author{
5 Secretaria de Meio Ambiente de Mato Grosso, \\ Superintendência de Fiscalização, Cuiabá, MT, Brasil. \\ 6 Independent consultant. Cuiabá, MT, Brasil. \\ * Corresponding author. \\ guilhermeroquette@yahoo.com.br
}

\begin{abstract}
The objectives of this research were to verify the relationships between the dendrometric and edaphic variables with the yield of oleoresin from Copaifera spp., and to adjust equations to predict yield from a primary forest. Thirty Copaifera spp. trees were selected to extract oleoresins over 24 hours, using a $1.91 \mathrm{~cm} \mathrm{(3/4} \mathrm{inch)} \mathrm{auger.} \mathrm{In} \mathrm{addition,} \mathrm{data} \mathrm{were} \mathrm{collected} \mathrm{on} \mathrm{tree} \mathrm{size} \mathrm{and} \mathrm{the} \mathrm{edaphic} \mathrm{characteristics} \mathrm{of}$ the topsoil around of each tree. Principal components analysis was used to verify the relationships between variables and a regression analysis was used to verify variables that may be best to predict oleoresin yield. After the principal components analysis, the only variable related to the oleoresin yield was the stem height, which had the best adjusted coefficient of determination (0.84) and relative standard error $(13.11 \%)$. We found the yield of oleoresin from Copaifera spp. in primary a forest had a significant and positive correlation with the stem height, whereas no significant correlations were found between yield, or any other dendrometric or topsoil variables studied.
\end{abstract}

KEYWORDS: Amazon specie, copaiba; forest exploitation, non-timber forest products, principal components analysis, regression analysis.

\section{RESUMEN}

El objetivo de este estudio fue investigar la relación entre las variables dendrométricas y del suelo con el rendimiento de aceite de Copaifera spp. y ajustar una ecuación para predecir la productividad en bosque primario. En el área de la investigación, 30 árboles de Copaifera spp. fueron seleccionados como muestras para la extracción del aceite por un período de 24 horas, con el uso de la barrena con $1,91 \mathrm{~cm}$ (3/4"). Además, fueron colectadas informaciones sobre el tamaño de los árboles y las características del suelo superficial en los alrededores de cada árbol. Se aplicó el análisis de componentes principales para verificar la relación de las variables con el rendimiento de aceite y, posteriormente, fue ajustada una ecuación para predecir este rendimiento mediante análisis de regresión. La única variable relacionada con el rendimiento de aceite fue la altura del fuste, y fue selecionada como el modelo que presentó mejor coeficiente de determinácion $(0,84)$ y error típico de estimación $(13,11 \%)$. Por lo tanto, se concluyó que el rendimiento del aceite de Copaifera spp. en bosque primario tiene una correlación positiva y significativa con la altura del fuste, mientras que las otras variables dendrométricas y del suelo superficial no presentaron correlación significativa con el rendimiento de aceite.

PALABRAS ClAVE: especie amazónica, copaiba, explotación forestal, producto no maderable, análisis de componentes principales, análisis de regresión. 


\section{INTRODUCTION}

Commercial explotation of forest products, including ecossystem services, is considered by Herrero-Jáuregui (2010) as one of the strategies to successfully reconcile economic development with nature conservation. Many non-timber forest products are gaining prominence on the international market, such as oleoresin from Copaifera spp. These species have potential for sustainable exploitation in multiple-use forest management systems, which are important for forest conservation, and maintaining extractive populations (Baima, Santos, Nunes \& Carvalho, 1999; Barbosa, Scudeller \& Rosa, 2009; RigamonteAzevedo, 2004).

The "copaiba" trees are species from the Copaifera genus (family: Fabaceae) that are native from the tropical regions of Latin America and West Africa. These trees produce an oleoresin that can be used for multiples applications; including being a source for active ingredients in pharmacology studies for numerous pathologies (Leandro et al., 2012; Lima, Veiga-Junior, Christo, Pinto, \& Fernandes, 2003; Veiga-Junior, \& Pinto, 2002). Copaiba oleoresin is a secondary product of a tree's metabolism, resulting in tree excretions working as defensive mechanism against intrusions by animals, fungi, or bacteria (Alencar, 1982; Langenheim, 2003; Phillips \& Croteau, 1999). The compounds are synthesized in parenchymal cells, lining pockets in the leaves, young stems, and elongated canals that formed by the separation of the cells, known as schizogeny (Langenheim, 1973). The yield of oleoresin from Copaifera spp. is highly variable, with reports of yields of approximately $30 \mathrm{~L}$ per extraction. However, such yields should be considered as a possible maximum, as mean yields have been found to vary between $0.3 \mathrm{~L}$ up to $3.0 \mathrm{~L}$ per extraction (Rigamonte-Azevedo, Wadt, \& Wadt, 2004).

Many researchers have tried to identify the factors that influence oleoresin production from Copaifera spp., relating differences to species of the genus, the size of the trees, the seasonality of extraction, the position of trees in the landscape, plus other environmental and genetic characteristics (Alencar, 1982; Baima et al., 1999; Barbosa et al., 2009; Ferreira \& Braz, 2001; Martins et al., 2013; Medeiros \& Vieira, 2008; Medeiros, Vieira, Almeida, \& Tomazello Filho, 2018; Newton, Watkinson, \& Peres, 2011; Oliveira, Lameira, \& Zoghbi, 2006; Plowden, 2001; 2003; Rigamonte-Azevedo et al., 2004; Rigamonte-Azevedo, Wadt, \& Wadt, 2006; Roquette et al., 2018; Wadtet al., 2007). Although diverse studies have attempted to identify the factors that interfered in the yield of oleoresin, no consensus has been reached about the factors that determine the oleoresin yield from Copaifera spp. Research conducted to date has raised the hypothesis that genetic and physiological factors are related to the production of copaiba oleoresin (Alencar, 1982; Martins et al., 2013; Medeiros \& Vieira, 2008). However, tree physiological processes may affect yield, which could vary by forest type, hydrology, soil fertility, growth, interspecific competition, and intensity of exploitation (Alencar, 1982; Medeiros \& Vieira, 2008; Medeiros et al., 2018; Newton et al., 2011; Plowden, 2003; Roquette et al., 2018). In addition, tree size has also been highlighted as a determinant factor of yield, due to the relationships between physiological activity and tree growth with the production of copaiba oleoresin (Medeiros \& Vieira, 2008; Medeiros et al., 2018; Roquette et al., 2018).

Newton et al. (2011) states that understanding the relationships between genetic, morphological, and environmental factors, with the production of non-timber products, is key to creating sustainable extraction protocols for resources. This knowledge is particularly important for copaiba oleoresin, since commercial production is a relatively recent practice, and technical and scientific studies on the production process and sustainable management are at an early stage (Klauberg, Vidal, Rodriguez, \& DiazBalteiro, 2014). The ability to estimate yield of copaiba oleoresin is important for planning and managing production. Thus, our hypothesis is that there are variables related to tree size, soil fertility or possibly both, that may be used to predict oleoresin yield in a natural population of Copaifera spp. in a primary. 


\section{OBJECTIVES}

The objectives of this research were to identify relationships between dendrometric and topsoil variables for the prediction of yield of Copaifera spp. oleoresin.

\section{MATERIALS AND METHODS}

\section{Study area}

The research was conduct in 213 ha of a primary forest, situated in the Municipality of Vera in the central-north region of the State of Mato Grosso, Brazil (Fig. 1). The area is located at $12^{\circ} 42^{\prime} 54^{\prime \prime} \mathrm{S}$ and $55^{\circ} 19^{\prime} 53^{\prime \prime} \mathrm{W}$ (DATUM WGS84), at an altitude of around $330 \mathrm{~m}$ above sea level.

The region is in the Amazon River watershed with the study area confined between the Macaco stream and its tributary, the Maluco stream. The vegetation is classified as lowland semideciduous seasonal forest with an emergent canopy, characterized by overstory species living along the Amazon that cover understory species found in the cerrado and rainforest (Instituto Brasileiro de Geografia e Estatística [IBGE], 2012). This area originated in the Cenozoic Era, and was formed by a basal zone that contains altered subjacent rocks, sands, clays, and partially lateralized conglomerate levels. A median area consists of compact ferruginous laterites, and an upper layer of clay soil. The soil is classified as a dystrophic yellow red latosol, plinthic and typical, with a medium texture. The topography, formed by an accumulation of sediments, is known as Parecis's Plateau (IBGE, 2009a; 2009b; 2009c). The typical climate of the region, which has a Köppen classification of Aw, is humid the majority of the year, presenting only three dry months, and with a average temperature above $18{ }^{\circ} \mathrm{C}$, and an annual rainfall of $1850 \mathrm{~mm}$ to $2050 \mathrm{~mm}$ (Instituto Nacional de Meteorologia, 1992).

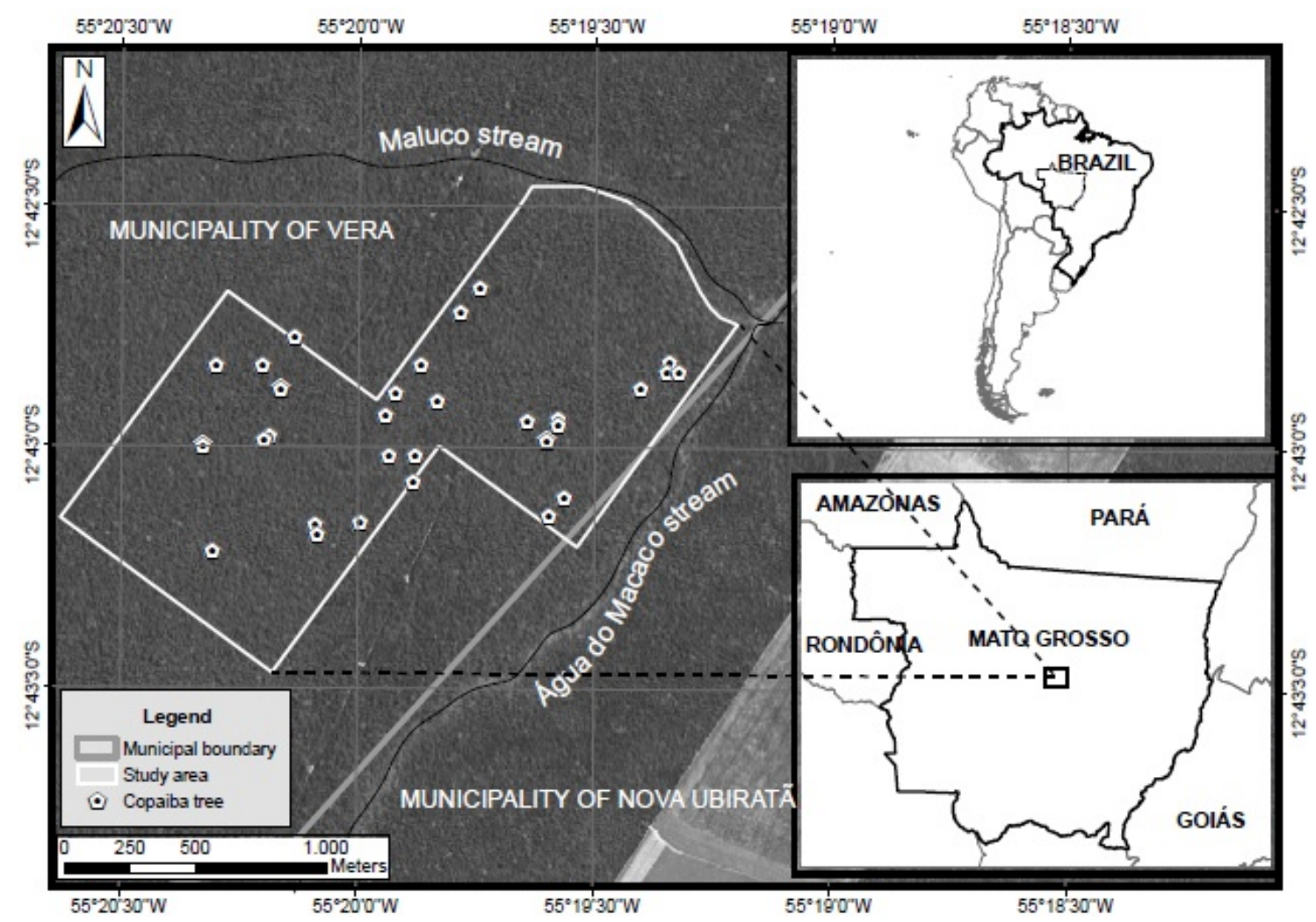

FIGURE 1. Location of the study area in a primary forest in the central-north region of the State of Mato Grosso, Brazil. 
Mapping the Copaifera spp. trees and oleoresin extraction

A forest inventory (census) of the study area for forest timber exploitation (unpublished data), identified 72 Copaifera spp. trees with a diameter at breast height (DBH) over $25 \mathrm{~cm}$ had a density of 2.96 trees $\mathrm{ha}^{-1}$. From these trees, 30 were selected for data collection, using DBH and distances from the streams in the limits of the study area as selection criteria. From this group of trees, seven trees were selected in a $30 \mathrm{~cm}-42 \mathrm{~cm}$ DBH class; six trees were selected in a $42 \mathrm{~cm}-54 \mathrm{~cm}$ DBH class 11 trees were selected in a $54 \mathrm{~cm}-66 \mathrm{~cm} \mathrm{DBH}$ class; and six trees were selected in a $66 \mathrm{~cm}-78 \mathrm{~cm}$ DBH class. All selected trees had never been drilled previously for oleoresin extraction. All trees were geo-referenced with a GPS unit that had a precision between $3 \mathrm{~m}$ and $5 \mathrm{~m}$. The extraction of oleoresin from the Copaifera spp. was made during the months of July, August, and September of 2012, corresponding to the region's dry season. The extraction procedures were similar to methods described in Roquette et al. (2018).

\section{Mensuration of dendrometric variables}

The circumference at breast height $(\mathrm{CBH})(\mathrm{cm})$ of each tree was measured with a tape measure. $\mathrm{CBH}$ was converted to DBH $(\mathrm{cm})$ according to the formula $\mathrm{DBH}=\mathrm{CBH} / \pi$, where $\pi=3.1416$. Total height $(\mathrm{TH})(\mathrm{m})$ and the stem height (SH) (m) were measured with an electronic hypsometer. Crown height $(\mathrm{CH})(\mathrm{m})$ was calculated by subtracting the TH from $\mathrm{SH}$. The Dc was calculated using the measurement of largest crown diameter observed from the ground, and the perpendicular to this measurement. The age and mean annual increment (MAI) $\left(\mathrm{cm} \mathrm{yr}^{-1}\right)$ of DBH were obtained as described in Roquette et al. (2018).

\section{Soil collection and analysis}

Around each tree four topsoil samples were collected to obtain a representative sample. The collections were made in a crosswise orientation, approximately $3 \mathrm{~m}$ from each tree, to a depth between $10 \mathrm{~cm}$ and $15 \mathrm{~cm}$, using a straight blade and a machete. Following collection, the topsoil was stored in plastic bags for two days before being sent for laboratory analysis. Eleven physical and chemical topsoil parameters were measured following procedures from Silva, Eira, Barreto, Pérez, and Silva (1998), and the VanRaij, Andrade, Cantarella, and Quaggio (2001) (Table 1). Other topsoil parameters measured around each Copaifera spp. trees were: sum of bases (S), saturation of bases (V), $\mathrm{Ca}^{2+} / \mathrm{Mg}^{2+}, \mathrm{Ca}^{2+} / \mathrm{K}^{+}$, and $\mathrm{Mg}^{2+} / \mathrm{K}^{+}$relationships, $\mathrm{Ca}^{2+}$ saturation (Ca sat), $\mathrm{Mg}^{2+}$ saturation (Mg sat), $\mathrm{K}^{+}$saturation (K sat), $\mathrm{H}^{+}$saturation (H sat), and $\mathrm{Al}^{3+}$ saturation (Al sat).

TABLE 1. Topsoil parameters and analytical methods used to analyze soils surrounding Copaifera spp. trees in a primary forest in the central-north region of the State of Mato Grosso, Brazil.

\begin{tabular}{|c|c|}
\hline Topsoil Parameter & Analytical Method \\
\hline $\mathrm{pH}$ & Calcium chloride solution (O.01 M), in the proportion 1:2.5 soil to CaCI2 (Van-Raij et al., 2001). \\
\hline $\mathrm{P}$ and $\mathrm{K}+$ & $\begin{array}{l}\text { Extracted with } 0.05 \mathrm{M} \mathrm{HCl} \text { solution and } 0.025 \mathrm{M} \mathrm{H} 2 \mathrm{SO} 4 \text { (Mehlich-1), with P determined } \\
\text { spectroscopically and K by flame photometer (Silva et al., 1998). }\end{array}$ \\
\hline $\begin{array}{l}\mathrm{Ca} 2+, \mathrm{Mg} 2+\text {, and } \\
\mathrm{Al}+\end{array}$ & $\begin{array}{l}\text { Extracted with } 1 \mathrm{M} \text { potassium chloride (KCI) solution, with Ca and Mg determined by atomic absorption } \\
\text { spectrophotometer (AAS) and Al volumetrically by titration with sodium hydroxide (Silva et al., 1998). }\end{array}$ \\
\hline $\mathrm{H}+$ & $\begin{array}{l}\text { Potential acidity }(\mathrm{H}++\mathrm{Al} 3+) \text { extracted with calcium acetate solution to } \mathrm{pH}=7 \text {, and } \mathrm{H}+\text { calculated by the } \\
\text { formula } \mathrm{H}+(\mathrm{cmolc} / \mathrm{kg})=[(\mathrm{H}++\mathrm{Al} 3+)-(\mathrm{Al} 3+)] \text { (Empresa Brasileira de Pesquisa Agropecuária, 1997) }\end{array}$ \\
\hline $\begin{array}{l}\text { Organic Matter } \\
\qquad(\mathrm{OM})\end{array}$ & Oxidation with potassium bichromate and colorimetric determination (Van-Raij et al., 2001). \\
\hline Sand, silt, and clay & $\begin{array}{c}\mathrm{NaOH} \text { dispersant and determination by the densimeter method (Empresa Brasileira de Pesquisa } \\
\text { Agropecuária, 1997) }\end{array}$ \\
\hline
\end{tabular}




\section{Data analysis and processing}

The relationships between dendrometric and edaphic variables, with the yield of Copaifera spp. oleoresin, were verified with a factorial analysis using principal components analysis (PCA). The PCA used a Pearson correlation matrix as input data, which was created from the variables shown in table 2. All factors with eigenvalue greater than one (latent root criterion) were retained. Next, the factors were rotated by the varimax method (orthogonal rotation) to simplify the factorial matrix and diminish ambiguities of the preliminary analysis, thus reducing the number of crossloadings. Correlations between factors and variables were considered significant when the value of the factor loading was greater than or equal to 0.5 (Hair, Black, Babin, Anderson, \& Tatham, 2009).

After the PCA was used to select variables that had high correlations to the oleoresin yield, a multiple regression analysis was conducted to improve equations for estimating oleoresin yield. To improve the correlations among estimated variables, the variables were transformed prior to being used in a stepwise regression analysis. Following the development of the regression equations, variables were selected for graphic analysis of residuals from four equations that presented together, had the highest adjusted coefficient of determination $\left(\mathrm{R}^{2}\right.$ adjusted), the lowest standard errors of the estimate $\left(\mathrm{SE}_{\mathrm{yx}} \%\right)$, and the significance (at a $5 \%$ level of probability error) according to a " $t$ " test to the adjusted coefficients, and a " $F$ " test of the regression equations.

\section{RESULtS}

The relationship between the dendrometric and edaphic variables and the yield of oleoresin from Copaifera spp.

After the varimax rotation, eight factors with eigenvalues above one were extracted by PCA analysis (accumulated variability: $\mathrm{F} 1=30.29 \% ; \mathrm{F}=42.72 \% ; \mathrm{F} 3=49.66 \% ; \mathrm{F} 4=$ $56.07 \% ; \mathrm{F} 5=62.04 \% ; \mathrm{F} 6=76.74 \% ; \mathrm{F} 7=85.88 \%$; and F8 $=91.48 \%$ ). The quantity of factors extracted denotes the large variation inherent to the data, as well as the low relationships between many of the variables. This can be attributed to the nature of the data, which was divided into two distinct groups related to the trees size, or to edaphic characteristics. Following the orthogonal rotation of the factors extracted, the interpretation of the factorial matrix permitted the grouping of the variables and the identification of variables most correlated with each factor (Table 3). SH was the only variable significantly correlated to the factor with oleoresin yield. In the factorial diagram of the PCA (Fig. 2), it was noted that the dendrometric and edaphic variables were placed into distinct groups. In addition, the yield of copaiba oleoresin showed a significant correlation only with SH $(r=0.53)$. Therefore, this was the only variable selected for adjusting equations for estimating oleoresin yield.

\section{Adjustment to the equations estimating the oleoresin yield}

The Copaifera spp. samples in the lowest DBH class $(30 \mathrm{~cm}$ - $42 \mathrm{~cm}$ ) were not productive. Other studies have also pointed out that trees with DBH less than $40 \mathrm{~cm}$ are not productive or produce low quantity of oleoresin (Alencar, 1982; Barbosa et al., 2009; Medeiros \& Vieira, 2008; Medeiros et al., 2018; Plowden, 2001; 2003; RigamonteAzevedo et al., 2006; Souza \& Higuchi, 2014). Therefore, the data from Copaifera spp. included in these DBH class were excluded, so as to not influence the adjustments to the equations estimating the oleoresin yield from SH. Tables 4 and 5 contain, respectively, the selected models for the graphic analysis of residuals (Fig. 3), as well as the statistical parameters associated with the regression equations.

The stepwise regression analysis resulted in satisfactory adjustments for the equations tested after the transformations of the variables (Table 5), representing approximately $80 \%$ of the variation in oleoresin yield explained by variations in $\mathrm{SH}$, considering the highest

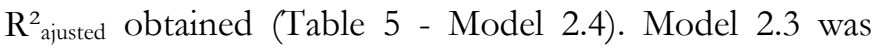
excluded from the selection of the optimal model because the intercept value was insignificant $(p<0.05)$ by the $t$-test. Except for Model 2.1, the residuals graphs showed a similar 
TABLE 2. Variables (mean + standard deviation) used in the PCA for verifying relationships between oleoresin yield from the Copaifera spp. trees analyzed in a primary forest in the central-north region of the State of Mato Grosso, Brazil.

\begin{tabular}{|c|c|c|}
\hline \multicolumn{3}{|c|}{ Dendrometric Variables } \\
\hline $\mathrm{DBH}(54.1 \pm 13.3) \mathrm{cm}$ & $\mathrm{CH}(11.2 \pm 4.5) \mathrm{m}$ & $\mathrm{TH}(23.7 \pm 4.7) \mathrm{m}$ \\
\hline \multirow[t]{2}{*}{$\mathrm{SH}(12.5 \pm 2.7) \mathrm{m}$} & $C D(13.5 \pm 4.4) m$ & $\mathrm{~A}(83 \pm 29) \mathrm{yr}$ \\
\hline & $\operatorname{MAI}(0.68 \pm 0.11) \mathrm{cm} \mathrm{yr}^{-1}$ & \\
\hline \multicolumn{3}{|c|}{ Edaphic Variables } \\
\hline $\mathrm{PH}(3.9 \pm 0.2)$ & $\mathrm{Ca}(0.4 \pm 0.1) \mathrm{cmol}_{\mathrm{c}} \mathrm{dm}^{-3}$ & $\mathrm{Al}(1.2 \pm 0.4) \mathrm{cmol}_{\mathrm{c}} \mathrm{dm}^{-3}$ \\
\hline$P(1.5 \pm 0.3) \mathrm{mg} \mathrm{dm}^{-3}$ & $\mathrm{Mg}(0.21 \pm 0.07) \mathrm{cmol}_{\mathrm{c}} \mathrm{dm}^{-3}$ & $\mathrm{~S}(0.7 \pm 0.2) \mathrm{cmolc}_{\mathrm{cm}} \mathrm{dm}^{-3}$ \\
\hline O.M. $(31.6 \pm 6.6) \mathrm{g} \mathrm{dm}^{-3}$ & Sand $(570 \pm 113) \mathrm{g} \mathrm{kg}^{-1}$ & $\mathrm{H}(5.8 \pm 1.3) \mathrm{cmol}_{\mathrm{c}} \mathrm{dm}^{-3}$ \\
\hline $\mathrm{K}(19.60 \pm 3.78) \mathrm{mg} \mathrm{dm}^{-3}$ & Silt $(99 \pm 26) \mathrm{g} \mathrm{kg}^{-1}$ & $\vee(8 \% \pm 2 \%)$ \\
\hline $\mathrm{Ca} / \mathrm{K}(7.4 \pm 3.0)$ & Clay (331 \pm 89$) \mathrm{g} \mathrm{kg}^{-1}$ & $\mathrm{Ca} / \mathrm{Mg}(1.6 \pm 0.3)$ \\
\hline $\mathrm{Mg} / \mathrm{K}(4.5 \pm 1.6)$ & Sat.Ca $(4.7 \% \pm 1.6 \%)$ & Sat.Mg $(2.9 \% \pm 0.7 \%)$ \\
\hline Sat.K (0.7\% $\pm 0.2 \%)$ & Sat.H $(75.2 \% \pm 3.5 \%)$ & Sat.Al $(64.4 \% \pm 12.9 \%)$ \\
\hline
\end{tabular}

$\overline{\mathrm{DBH}}=$ diameter at breast height; $\mathrm{TH}=$ total height; $\mathrm{SH}=$ stem height; $\mathrm{CH}=$ crown height; $\mathrm{CD}=$ mean crown diameter; $\mathrm{A}=\mathrm{age} ; \mathrm{MAl}=$ mean annual increment of $\mathrm{DBH} ; \mathrm{P}=$ phosphorus; $\mathrm{K}$ = potassium; $\mathrm{Ca}$ = calcium; $\mathrm{Mg}$ = magnesium; $\mathrm{Al}$ = aluminium; $\mathrm{H}$ = hydrogen; $\mathrm{OM}=$ organic matter; $\mathrm{S}=$ sum of bases; $\mathrm{V}=$ saturation of bases; $\mathrm{Ca} / \mathrm{Mg}$ = $\mathrm{Ca}^{2+} / \mathrm{Mg}^{2+}$ relationship; $\mathrm{Ca} / \mathrm{K}=\mathrm{Ca}^{2+} / \mathrm{K}^{+}$relationship; $\mathrm{Mg} / \mathrm{K}=\mathrm{Mg}^{2+} / \mathrm{K}^{+}$relationship; $\mathrm{Ca}$ sat $=\mathrm{Ca}^{2+}$ saturation; $\mathrm{Mg}$ sat $=\mathrm{Mg}^{2+}$ saturation; $\mathrm{K}$ sat $=\mathrm{K}^{+}$saturation; $\mathrm{H}$ sat $=\mathrm{H}^{+}$ saturation; and $\mathrm{Al}$ sat $=\mathrm{Al}^{\mathrm{\beta}+}$ saturation.

patterns of residuals distribution (Fig. 3). In all models selected, an atypical observation was noted, which consisted of the tree with the highest SH $(19.3 \mathrm{~m})$ also having the highest oleoresin yield $(2.35 \mathrm{~L})$. In addition, the tree with the second highest SH $(18.6 \mathrm{~m})$ had the second highest oleoresin yield $(0.5 \mathrm{~L})$; however, the yield was closer to values observed for the other productive Copaifera spp. trees.

Although Models 2.2 and 2.4 presented better $\mathrm{R}_{\text {adjusted }}$ and $\mathrm{SE}_{\mathrm{yx}} \%$ results than Model 2.1, Model 2.1 was selected as the optimal model for equation adjustment due to the lower residue amplitude for the trees with greater $\mathrm{SH}$. Model 2.1 possessed the poorest $\mathrm{R}^{2}$ adjusted and $\mathrm{SE}_{\mathrm{yx}} \%$ parameters among the four models selected for analysis. However, Model 2.1 was considered the better model for adjusting an equation because the oleoresin yield estimate error of the tree with the highest $\mathrm{SH}$ was lower than the errors observed in the Models 2.2 and 2.4, as shown in figure 3. In the future, this will allow for a smaller error when other Copaifera spp. trees with similar characteristics are studied.

\section{DISCUSSION}

There were no significant correlations between the copaiba oleoresin yield and the attributes related to soil fertility. Thus, the soil characteristics that influence the production mentioned by Alencar (1982) and Newton et al. (2011) may be related to water availability in the extraction period, or indirect factors related to tree physiology and macrohabitat characteristics. Some researchers have observed that in the rainy season in clayey soils, the yield of oleoresin is higher, possibly due to the higher water availability (Alencar et al., 1982; Barbosa et al., 2009; Plowden, 2003). In recent research, Medeiros et al. (2008) observed that the volume of oleoresin is more related to the availability of water in the soil than the mean seasonal precipitation, although more long-term studies are needed to prove this relationship. Research conducted by Alencar (1982), Barbosa et al. (2009), Martins et al. (2013), Plowden (2001; 2003), and Rigamonte-Azevedo et al. (2006), did not observe significative correlations between oleoresin yield and $\mathrm{DBH}$. However, Medeiros \& Vieira (2008) observed correlations 
TABLE 3. Significant factorial loads post-varimax rotation and grouping of variables into the factors extracted from the PCA after varimax rotation for variables studied in a primary forest in the central-north region of the State of Mato Grosso, Brazil.

\begin{tabular}{|c|c|c|c|c|c|c|c|c|}
\hline & $F l$ & $F 2$ & F3 & $F 4$ & F5 & F6 & F7 & F8 \\
\hline $\mathrm{pH}$ & 0.706 & & & & & & & \\
\hline $\mathrm{Ca}$ & 0.836 & & & & & & & \\
\hline $\mathrm{Mg}$ & 0.810 & & & & & & & \\
\hline Al & -0.930 & & & & & & & \\
\hline (S) & 0.865 & & & & & & & \\
\hline (V) & 0.967 & & & & & & & \\
\hline $\mathrm{Ca} / \mathrm{K}$ & 0.725 & & & & & & & \\
\hline $\mathrm{Mg} / \mathrm{K}$ & 0.624 & & & & & & & \\
\hline Sat. Ca & 0.947 & & & & & & & \\
\hline Sat. Mg & 0.943 & & & & & & & \\
\hline Sat. H & 0.672 & 0.546 & & & & & & \\
\hline Sat. Al & -0.969 & & & & & & & \\
\hline $\mathrm{H}$ & & 0.929 & & & & & & \\
\hline O.M. & & 0.893 & & & & & & \\
\hline Sat. K & & -0.629 & & & & -0.527 & & \\
\hline Age & & & 0.799 & & & & & \\
\hline MAI & & & -0.945 & & & & & \\
\hline$C D$ & & & & 0.518 & & & & \\
\hline$P$ & & & & -0.623 & & & & \\
\hline K & & & & 0.743 & & & & \\
\hline $\mathrm{SH}$ & & & & & 0.822 & & & \\
\hline Oleoresin & & & & & 0.877 & & & \\
\hline Sand & & & & & & -0.928 & & \\
\hline Silt & & & & & & 0.887 & & \\
\hline Clay & & & & & & 0.927 & & \\
\hline $\mathrm{DBH}$ & & & & & & & 0.646 & \\
\hline TH & & & & & & & 0.940 & \\
\hline $\mathrm{CH}$ & & & & & & & 0.914 & \\
\hline $\mathrm{Ca} / \mathrm{Mg}$ & & & & & & & & 0.886 \\
\hline
\end{tabular}

$\mathrm{DBH}=$ diameter at breast height; $\mathrm{TH}=$ total height; $\mathrm{SH}=$ stem height; $\mathrm{CH}=$ crown height; $\mathrm{CD}=$ mean crown diameter; $\mathrm{MAl}=$ mean annual increment of DBH; $\mathrm{P}=\mathrm{ph}$ osphorus; $\mathrm{K}=$ potassium; $\mathrm{Ca}$ = calcium; $\mathrm{Mg}=$ magnesium; $\mathrm{Al}=$ aluminum; $\mathrm{H}=$ hydrogen; $\mathrm{OM}=$ organic matter; $\mathrm{S}=$ sum of bases; $\mathrm{V}=$ saturation of bases; $\mathrm{Ca}_{\mathrm{Mg}}=\mathrm{Ca}{ }^{2+} / \mathrm{Mg}^{2+}$ relationship; $\mathrm{Ca} / \mathrm{K}=\mathrm{Ca}^{2+} / \mathrm{K}^{+}$relationship; $\mathrm{Mg} / \mathrm{K}=\mathrm{Mg}^{2+} / \mathrm{K}^{+}$relationship; Sat. $\mathrm{Ca}=$ saturation by $\mathrm{Ca}^{2+} ; \mathrm{Sat} . \mathrm{Mg}$ = saturation by $\mathrm{Mg}^{2+}$; Sat. $\mathrm{K}=$ saturation by $\mathrm{K}^{+} ; \mathrm{Sat}$. $\mathrm{H}=$ saturation by $\mathrm{H}^{+}$, and $\mathrm{Sat}$. $\mathrm{Al}=$ saturation by $\mathrm{Al}^{\mathrm{3}}$. Fl, F2, F3... F7 = extracted factor by the PCA. 


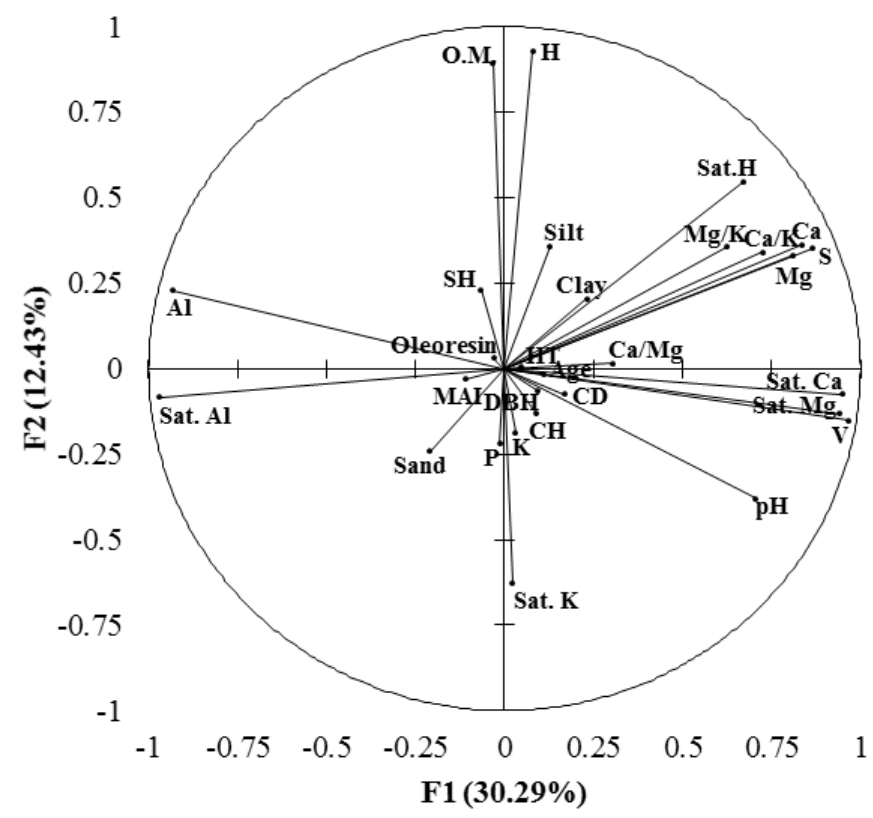

FIGURE 2. Factorial diagram of the principal components after rotation of the factors by the varimax method to the studied variables of the Copaifera spp. trees in a primary forest in the central-north region of the State of Mato Grosso, Brazil.

TABLE 4. Models selected to estimate oleoresin yield using stem height (SH) for the Copaifera spp. trees studied in a primary forest in the central-north region of the State of Mato Grosso, Brazil.

\begin{tabular}{lc}
\hline & Models \\
\hline 2.1 & $\frac{1}{\left(0.1+\mathrm{y}^{2}\right)}=\beta_{0}+\beta_{1} \frac{1}{\mathrm{SH}}+\beta_{2}\left(\mathrm{SH} * \mathrm{SH}^{2} * \mathrm{SH}^{3} * \sqrt{\mathrm{SH})}\right.$ \\
2.2 & $\frac{1}{\left(0.1+\mathrm{y}^{3}\right)}=\beta_{0}+\beta_{1} \mathrm{SH}+\beta_{2} \mathrm{SH}^{2}+\beta_{3} \mathrm{SH}^{3}$ \\
2.4 & $\frac{1}{\left(0.1+\mathrm{y}^{2}\right)}=\beta_{0}+\beta_{1} \mathrm{SH}^{2}+\beta_{2} \mathrm{SH}^{3}$ \\
$\frac{1}{\left(0.1+\mathrm{y}^{3}\right)}=$ & $\beta_{0}+\beta_{1}\left(\mathrm{SH} * \mathrm{SH}^{2}\right)+\beta_{2}\left(\mathrm{SH} * \mathrm{SH}^{2} * \mathrm{SH}^{3} * \sqrt{\mathrm{SH}}\right)$ \\
\hline
\end{tabular}

$\mathrm{y}=$ oleoresin yield (I) SH = stem height (m).

TABLE 5. Statistical parameters of the models selected for the estimation of the oleoresin yield as a function of stem height (SH) for the Copaifera sp. trees studied in a primary forest in the central-north region of the State of Mato Grosso, Brazil.

\begin{tabular}{cccccccc}
\hline Model & $\beta_{0}$ & $\beta_{1}$ & $\beta_{2}$ & $\beta_{3}$ & $R^{2}$ adjust. & $S_{y \times} \%$ & $F$ \\
\hline 2.1 & $16.375^{*}$ & $-0.047^{*}$ & $-9.378^{*}$ & - & 0.85 & 13.11 & $50.41^{*}$ \\
2.2 & $26.925^{*}$ & $-5.725^{*}$ & $0.578^{*}$ & $0.018^{*}$ & 0.94 & 6.78 & $99.82^{*}$ \\
2.3 & $1.201^{\text {ns }}$ & $0.163^{*}$ & $-0.009^{*}$ & - & 0.85 & 12.97 & $51.68^{*}$ \\
2.4 & $8.064^{*}$ & $0.002^{*}$ & - & - & 0.95 & 6.12 & $184.96^{*}$ \\
\hline
\end{tabular}

$\beta 0=$ intercept; $\beta \mathrm{i}=$ regression coefficients; $R^{2}$ adjusted = adjusted coefficient of determination; $S E_{y x} \%$ = standard error of the estimate; and $F=F$ ratio for significance of the model. ${ }^{*}$ Significant $\left(p<0.05\right.$ ) by the t-test for $\beta_{0}, \beta_{1}, \beta_{2}$ and $\beta_{3}$ and by the $F$ test for the model. ns Not significant ( $\left.p<0.05\right)$ by the t-test for $\beta_{0}, \beta_{1}, \beta_{2}$ and $\beta_{3}$ and by the $F$ test for the model. 
Model 2.1

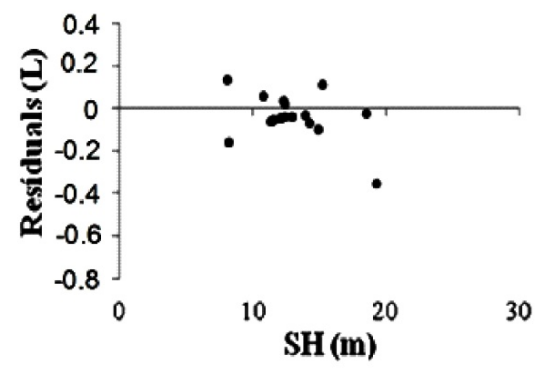

Model 2.3

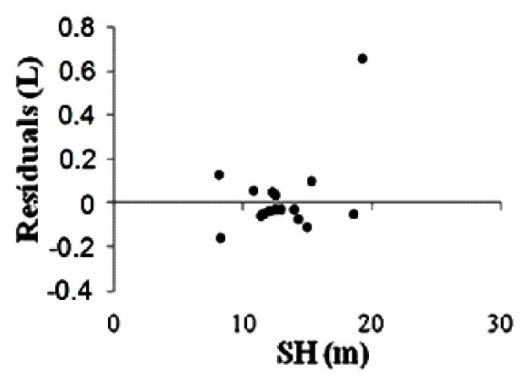

Model 2.2

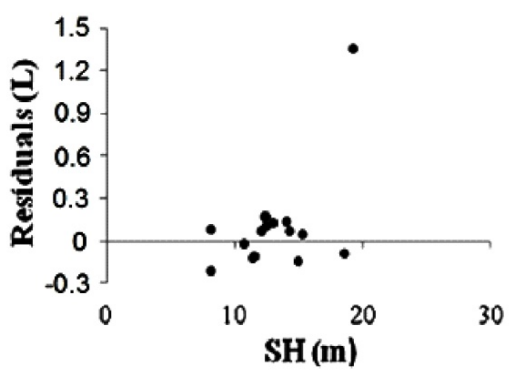

Model 2.4

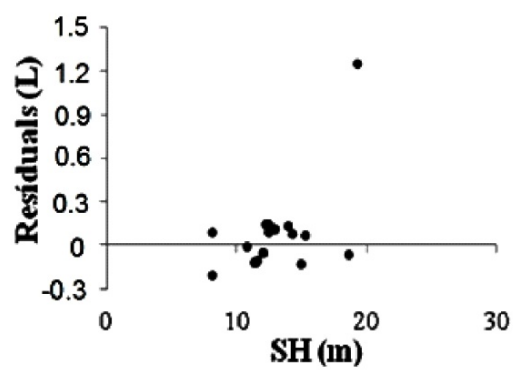

FIGURE 3. Residuals graphic of the estimation models for oleoresin yield as a function of stem height $(\mathrm{SH})$ for the Copaifera spp. trees studied in a primary forest in the central-north region of the State of Mato Grosso, Brazil.

between the oleoresin yield and DBH in two successive collections, with the first collection correlations being significative and positive. Moreover, some studies found that Copaifera spp. trees with smaller and larger diameters tend to produce little or no oleoresin, with the intermediate diameter classes having the greatest yields (Alencar, 1982; Barbosa et al., 2009; Medeiros et al., 2018; Plowden, 2001; 2003; Rigamonte-Azevedo et al., 2006; Roquette et al., 2018; Souza \& Higuchi, 2014).

$\mathrm{DBH}$ is related to the age of trees, but in natural forests there is a greater variation in this relationship due to the complex interactions present in the ecosystem. However, because there is a minimum age to start oleoresin extraction and yield is reduced during times of senescence, other factors must be considered in the selection of trees for production (Medeiros et al., 2018; Plowden, 2003; Roquette et al., 2018). A more refined discussion between the relationship of $\mathrm{DBH}$, age and tree growth of a studied population can be found in Roquette et al. (2018).
Some authors applied linear regression analysis to estimate yields of oleoresin from Copaifera spp. in studies conducted in different regions of the Amazon forest; but only used DBH as the predictor variable (Barbosa et al., 2009, Rigamonte-Azevedo et al., 2006). RigamonteAzevedo et al. (2006) concluded that the best adjusted model in their study could not be utilized to predict the copaiba oleoresin yield based on the $\mathrm{DBH}$; due to having coefficient of determination $\left(\mathrm{R}^{2}\right)$ values equal to 0.1 and a significance of approximately 37\%. Likewise, Barbosa et al. (2009) also did not obtain success in predicting oleoresin yield based on $\mathrm{DBH}$, having obtained an $\mathrm{R}^{2}$ value equal 0.26 for the equation adjusted.

Other dendrometric variables were evaluated in other studies, such as total height and crown measures, but none of them showed significant correlations with the copaiba oleoresin yield (Alencar, 1982; Plowden, 2001; 2003; Barbosa et al., 2009; Martins et al., 2013). The significant and positive relationship between the variance of the oleoresin yield and stem height found in this study, may be associated 
with the fact that the compound extracted was synthesized in the parenchymal cells in the secondary wood of trees (Langenheim, 1973), indicating that greater amounts of secondary wood will increase the probability of greater oleoresin yields. Moreover, Medeiros et al. (2008) found a positive and significant correlation between the oleoresin yield and the amount of heartwood in Copaifera spp. Thus, higher proportions of heartwood in tree diameter and height, as the results obtained in this study indicate, will probably result in higher oleoresin yields. However, studies related to tree trunk histology should be made to evaluate the quantity and disposition of these cells, and of the secretory canals along in the stem, to determine if these variables have a direct connection with oleoresin yield, and if there are other factors associated with oleoresin synthesis.

Results reported in Medeiros y Vieira (2008), from research conducted at the Adolpho Ducke Forest Reserve, in the Municipality of Manaus, Amazonas State, Brazil, suggest that the intensity of neighboring tree competition has a positive influence on oleoresin yield, when evaluated using biomass values or the relative dominance of the Copaifera spp. over competing trees. These results indicate that the ability to capture resources may be a determining factor for oleoresin yield, starting from the premise that production depends on the substances produced photosynthetically. This hypothesis, that competition to intercept solar energy by trees, resulting in trees having greater stem height growth, may be a strategy for increasing oleoresin yield. However, this strategy should first be investigated through experimental research and take into consideration the highly variable effects of competition on the development and production of plants, plus the influences of site characteristics on oleoresin production (Castro \& Garcia, 1996).

Martins et al. (2013) only found a relationship between oleoresin yield and the presence of hollows in the trees, which resulted in a negative yield. This result indicates that the health of trees can also affect oleoresin yield, which must be considered in the exploitation of this product. Moreover, results from Martins et al. (2013) support the hypothesis that the potential oleoresin yield from Copaifera spp. can vary by species. This hypothesis is also supported by Newton et al. (2011) and demonstrates that total oleoresin yield from Copaifera spp. may be affected by morphological and environmental factors. Therefore, the variability in copaiba oleoresin production that are potentially caused by morphological and environmental factors may have affected the results of this study.

\section{CONCLUSIONS}

Although many studies have not found significant correlations between oleoresin yield and other variables, the results in this work demonstrate that initially it is possible to predict oleoresin yield for the population studied in a primary forest using stem height as the explanatory variable for trees above $42 \mathrm{~cm} \mathrm{DBH}$ in the first extraction. This result could be applied in the management of natural or planted Copaifera spp. populations with the goal of largescale oleoresin extraction. The relationships found in this study between environmental and dendrometric factors, and oleoresin yield, provide valuable information to support the consolidation of a stable market for copaiba oleoresin production, for silvicultural treatments of Copaifera spp.

\section{ACINNOWLEDGEMENTS}

The authors would like to thank André Dias, Fernando Gava, Carlos Parizotto, Alan da Silva and Evandro Dall'Oglio for collaborating in this study.

\section{REFERENCES}

Alencar, J. (1982). Estudos silviculturais de uma população natural de Copaifera multijuga Hayne-Leguminosae, na Amazônia Central. 2 Produção de óleo-resina. Acta Amazonica, 12(1), 75-89. doi: $\underline{10.1590 / 1809-43921982121075}$

Baima, A. M. V., Santos, L. S., Nunes, D. S., \& Carvalho, J. O. P. (1999). Produção de óleo de copaíba na região do Tapajós. Comunicado Técnico EMBRAPA/CPATU, (103), 1-3.

Barbosa, K. S., Scudeller, V. V., \& Rosa, A. L. (2009). Potencial de produção de óleo resina de Copaifera multijuga Hayne nos dois períodos climáticos amazônico na Reserva de Desenvolvimento Sustentável do Tupé, Manaus-AM. In E. N. Santos-Silva \& V. V. Scudeller (Org.). Biotupé: Meio Físico, Diversidade Biológica e 
Sociocultural do Baixo do Rio Negro, Amazônia Central (pp. 143-153). Manaus, AM, Brazil: UEA Edições.

Castro, C., \& Garcia, R. (1996). Competição entre plantas com ênfase no recurso luz. Ciência Rural, 26(1), 167-174. doi: 10.1590/s0103$\underline{84781996000100031}$

Empresa Brasileira de Pesquisa Agropecuária. (1997). Manual de métodos de análise de solos (2a ed.), Rio de Janeiro, Brazil: EMBRAPACNPS.

Ferreira, L. A., \& Braz, E. M. (2001). Avaliação do potencial de extração e comercialização do óleo-resina de copaíba (Copaifera sp.). Florística e Botânica Econômica do Acre. The New York Botanical Garden/Universidade Federal do Acre, Brazil. Retrieved from http://www.nybg.org/bsci/acre/www1/evaluation.html

Hair, J. F., Black, W. C., Babin, B. J., Anderson, R. E., \& Tatham, R. L. (2009). Análise multivariada de dados (6th ed.). Grupo A - Bookman.

Herrero-Jáuregui, C. (2010). Gestión integrada de los recursos forestales en la Amazonía Oriental: ecología de dos especies de uso múltiple. Ecossistemas, 19(2), 155-160.

Instituto Brasileiro de Geografia e Estatística [IBGE] (2009a). Mapa de geologia do estado de Mato Grosso (1st ed.). Retrieved from ftp://geoftp.ibge.gov.br/informacoes ambientais/geologia/leva ntamento geologico/mapas/unidades da federacao/mt geolog ia.pdf

Instituto Brasileiro de Geografia e Estatística [IBGE] (2009b). Mapa de geomorfologia do estado de Mato Grosso (1st ed.). Retrieved from ftp://geoftp.ibge.gov.br/informacoes ambientais/geomorfologi a/mapas/unidades da federacao/mt geomorfologia.pdf

Instituto Brasileiro de Geografia e Estatística [IBGE] (2009c). Mapa de pedologia do estado de Mato Grosso (1st ed.). Retrieved from ftp://geoftp.ibge.gov.br/informacoes ambientais/pedologia/m apas/unidades da federacao/mt pedologia.pdf

Instituto Brasileiro de Geografia e Estatística [IBGE] (2012). Manual técnico da vegetação brasileira. Manuais técnicos em geociências (2nd ed.), 1, Rio de janeiro, Brazil: IBGE.

Instituto Nacional de Meteorologia (1992). Normais climatológicas do Brasil 1961-1990: precipitação acumulada mensal e anual (mm). Retrieved from

www.inmet.gov.br/portal/index.php? $\mathrm{r}=\mathrm{clima} /$ normaisClimatol ogicas

Klauberg, C., Vidal, E., Rodriguez, L. C. E., \& Diaz-Balteiro, L. (2014). Determining the optimal harvest cycle for copaíba (Copaifera spp.) oleoresin production. Agricultural Systems, 131, 116-122. doi: $\underline{10.1016 / j . a g s y .2014 .07 .007}$
Langenheim, J. H. (1973). Leguminous resin-producing trees. In B. J. Meggers, E. S. Ayensu, \& W. D. Duckworth. Tropical Forest Ecosystems in Africa and South America: a comparative review (pp. 89104). Washington, USA: Smithsonian Institution Press.

Langenheim, J. (2003). Plant resins (1st ed.). Portland, Or.: Timber Press.

Leandro, L., Vargas, F. S, Barbosa, P., Neves, J., da Silva, J., \& da VeigaJunior, V. (2012). Chemistry and Biological Activities of Terpenoids from Copaiba (Copaifera spp.) Oleoresins. Molecules, 17(12), 3866-3889. doi: 10.3390/molecules 17043866

Lima, S., Veiga Junior, V. F., Christo, H., Pinto, A., \& Fernandes, P. (2003). In vivo and in vitro studies on the anticancer activity of Copaifera multijuga Hayne and its fractions. Phytotherapy Research, 17(9), 1048-1053. doi: 10.1002/ptr.1295

Martins, K., Herrero-Jáuregui, C., da Costa, P., Tonini, H., Bentes-Gama, M., Vieira, A., \& Wadt, L. de O. (2013). Interspecific differences in the oleoresin production of Copaifera L. (Fabaceae) in the Amazon rainforest. Annals of Forest Science, 70(3), 319-328. doi: $\underline{10.1007 / \mathrm{s} 13595-012-0254-8}$

Medeiros, R. S., \& Vieira, G. (2008). Sustainability of extraction and production of copaiba (Copaifera multijuga Hayne) oleoresin in Manaus, AM, Brazil. Forest Ecology and Management, 256(3), 282288. doi: 10.1016/j.foreco.2008.04.041

Medeiros, R. S., Vieira, G., Almeida, D. R. A., \& Tomazello Filho. (2018). New information for managing Copaifera multijuga Hayne for oleoresin yield. Forest Ecology and Management, 414, 85-98. doi: $\underline{10.1016 / \text { i.foreco.2018.02.009 }}$

Newton, P., Watkinson, A., \& Peres, C. (2011). Determinants of yield in a non-timber forest product: Copaifera oleoresin in Amazonian extractive reserves. Forest Ecology and Management, 261(2), 255-264. doi: 10.1016/i.foreco.2010.10.014

Oliveira, E. C. P., Lameira, O. A., \& Zoghbi, M. G. B. (2006). Identificação da época de coleta do óleo-resina de copaíba (Copaifera sp.) no município de Moju, PA. Revista Brasileira de Plantas Medicinais, 8(3), 14-23.

Phillips, M., \& Croteau, R. (1999). Resin-based defenses in conifers. Trends In Plant Science, 4(5), 184-190. doi: 10.1016/s1360$\underline{1385(99) 01401-6}$

Plowden, C. (2001). The ecology, management and marketing of non-timber forest products in the Alto Rio Guamá indigenous reserve (eastern Brazillian Amazon) (Disertación doctoral). University Park, Pennsylvania State University, Pennsylvania, United States.

Plowden, C. (2003). Production ecology of Copaíba (Copaifera spp.) Oleoresin in the Eastern Brazilian Amazon. Economic Botany, 57(4), 491-501. doi: 10.1663/00130001(2003)057[0491:peoccs]2.0.co;2 
Rigamonte-Azevedo, O. C. (2004). Copaíba: estrutura populacional, producãa e qualidade do óleo-resina em populações nativas do sudoeste da Amazônia (Master thesis). Universidade Federal do Acre, Rio Branco, AC, Brazil.

Rigamonte-Azevedo, O. C., Wadt, P. G. S., \& Wadt, L. H. O. (2004). Copaíba: ecologia e produção de óleo-resina. Documento EMBRAPA, 91,1-28.

Rigamonte-Azevedo, O. C., Wadt, P. G. S., Wadt, L. H. O., Veiga-Junior, V. F., Pinto, A. C., \& Regiani, A. M. (2004). Variabilidade química e física do óleo-resina de Copaifera sp. no sudoeste da Amazônia brasileira. Revista Brasileira de Oleaginosas e Fibrosas, 8(2), 851-861.

Rigamonte-Azevedo, O. C., Wadt, P. G. S., \& Wadt, L. H. O. (2006). Potencial de produção de óleo-resina de copaíba (Copaifera sp.) de populações naturais do sudoeste da Amazônia. Revista Árvore, 30(4), 583-591.

Roquette, J. G., Drescher, R., Brondani, G. E., Souza, E. C., RondonNeto, R. M., Ebert, A., Teixeira, L. R., Dias, A. P., \& Gava, F. H. (2018). Age and growth affect oleoresin yield from copaiba trees in the Cerrado-Amazonia ecotone. Cerne, 24(2), 106-113. doi: $\underline{10.1590 / 01047760201824022527}$

Silva, F. C., Eira, P. A., Barreto, W. O., Pérez, D. V., \& Silva, C. A. (1998). Análise químicas para avaliação da fertilidade do solo: métodos usados na Embrapa Solos. Documento EMBRAPA/CNPS, (3), 140 .

Souza, F., \& Higuchi, N. (2014). O manejo da copaíba pelas etnias Arara e Gavião na Terra Indígena Igarapé Lourdes, Rondônia, Norte do Brasil. Revista Ceres, 61(1), 28-34. doi: 10.1590/s0034737x2014000100004

Van Raij, B., Andrade, J., Cantarella, H., \& Quaggio, J. (2001). Análise química para avaliação da fertilidade de solos tropicais (1st ed.). Campinas: Instituto Agronômico.

Veiga-Junior, V. F., \& Pinto, A. C. (2002). O gênero Copaifera L. Revista Quimica Nova, 25(2), 273-286.

Wadt, L. H. O., Martins, K., Herrero-Jáuregui, C., Araújo, E. A., Felinto, A. S., Vieira, A. H., \& Bentes-Gama, M. (2007). Efeito do tipo e época de extração na produção de óleo-resina de copaíba. In S. Rosso (Presidency), Ecologia nos tempos de mudanças globais. Conference held in VIII Congresso de Ecologia do Brasil, Caxambu, MG, Brazil.

Received: 11 December 2016

Accepted: 4 March 2019

Published: 13 December 2019

This paper must be cited as:

Roquette, J. G., Drescher, R., Brondani, G. E., Souza, E. C., Rondon-Neto, R. M., Ebert, A., \& Teixeira, L. R. (2019). Estimation of oleoresin yield from Copaifera spp. in primary forest in meridional Amazon. Madera y Bosques, 25(3), e2531475. doi: $10.21829 /$ myb.2531475

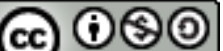

BY NC SA
Madera y Bosques by Instituto de Ecología, A.C. is distributed under a Creative Commons Licence Attribution-NonCommercial-ShareAlike $\quad 4.0$ Internacional. 